\title{
The Commonwealth Secretariat Arbitral Tribunal: The Evolution and Explanation of Changes to the Tribunal's Statute
}

\author{
Alice Lacourt*
}

\begin{abstract}
This chapter seeks to interrogate the rationale for the establishment of the Commonwealth Secretariat Arbitral Tribunal (CSAT) and examine how the Statute creating the Tribunal has evolved. Several applicants in the early cases before cSAT brought parallel litigation before the domestic courts of the United Kingdom. Arguments based on local law acted as a counterpoint to developments in the case law and Statute of cSAT. The resulting CSAT decisions delineated key principles on human rights and access to justice, which are still relevant today. CSAT — and the nature of the applications before it-continues to evolve, and this chapter concludes by identifying some lessons learned so far and what to expect going forward.
\end{abstract}

\section{Introduction}

This chapter is divided into six sections. In this first section, the domestic law framework of the Commonwealth Secretariat is considered, together with identifying the present-day principle features of the Commonwealth Secretariat Arbitral Tribunal (CSAT), as well as the wider context. Sections 2 and 3 provide a brief history of the Commonwealth Secretariat and overview of its organizational structure and governance, respectively. Section 4 examines how employment-related disputes were initially resolved at the Commonwealth Secretariat and the factors that led up to and informed the establishment of CSAT. Section 5 then analyses how the early cases before the Tribunal in fact shaped CSAT, together with the evolving roles of the Board of Governors

\footnotetext{
* Alice Lacourt, Legal Counsel, Commonwealth Secretariat, a.lacourt@commonwealth.int. I am grateful to colleagues, particularly the Commonwealth Secretariat Knowledge Centre and Archives team, for their contributions and comments. The views expressed are my own and do not necessarily reflect the views of the Commonwealth Secretariat.
} 
and the Commonwealth Secretariat. In conclusion, Section 6 considers the present-day and future roles of CSAT as well as suggesting some lessons-learned for the future.

\subsection{The Domestic Law Framework}

In 1966, the Parliament of the United Kingdom (UK) enacted the Commonwealth Secretariat Act to give effect to the 1965 Agreed Memorandum on the Commonwealth Secretariat. ${ }^{1}$ The Act conferred legal personality and granted the organization as well as its staff certain privileges and immunities. In 1995, the Governments of the Commonwealth decided to create a statute to establish an arbitral tribunal to hear contractual disputes, including disputes pertaining to employment relations within the Commonwealth Secretariat. As the Secretariat evolved, it had identified a real need to provide a dispute resolution forum at the international level without recourse to dispute resolution in domestic law and the need to waive immunity from local jurisdiction and enforcement. The creation of this tribunal, known as the Commonwealth Secretariat Arbitral Tribunal, followed the reluctance of local courts to adjudicate over cases brought by employees of the Commonwealth Secretariat in view of its immunity from jurisdiction. ${ }^{2}$

\subsection{The Principal Features of csat Today}

CSAT was established under Article I of the Statute. ${ }^{3}$ Article II explains the character of CSAT as an international administrative tribunal, with jurisdiction over applications by staff, the Secretariat or others contracting with it. ${ }^{4}$ There are eight members, including a President who presides over the first instance panel of three judges as described in Article IV. ${ }^{5}$ The Tribunal is supported by a suitably qualified lawyer as Executive Secretary, answerable only to the Tribunal, who is appointed by the Commonwealth Secretary-General in accordance with Article v. ${ }^{6}$ It always sits in London, although it can, under Article VII.2, convene elsewhere for reasons of efficiency and subject to budgetary considerations. $^{7}$

1 Agreed Memorandum on the Commonwealth Secretariat. On use of informal instruments, rather than treaties, in the Commonwealth see Aust 1986, 788.

2 Court of Appeal of England and Wales, Gadhokv Commonwealth Secretariat 1977.

3 Statute of the CSAT (Statute), art I.

4 Ibid, art II.

5 Ibid, art IV.

6 Ibid, art $\mathrm{v}$.

7 Ibid, art VII.2. 
The Tribunal decides by majority, as set out in Article IX, and its decisions are posted on the Tribunal's public website. ${ }^{8}$ Article $\mathrm{x}$ provides that the Tribunal may order the rescission of the decision, specific performance or, or in addition, compensation for any loss or damage. ${ }^{9}$ The President may convene a five-strong Review Board under Article XI, if a decision is challenged for error of fact or law or unreasonableness. The Review Board may substitute its own determination, order a re-hearing, or refuse to grant any remedy. Decisions are final and binding upon the parties..$^{10}$ Concerning applicable law, Article XII provides that in employment cases, international administrative law applies to the exclusion of domestic law, whereas in contract cases, CSAT applies the law specified in or most closely connected with the contract. ${ }^{11}$

\subsection{The Wider Context}

CSAT is one of many international administrative tribunals (IATs) created towards the end of the 2oth century for the purpose of adjudicating contractual disputes, principally staff employment claims, against international organizations. Since 1995, it has heard more than 40 cases. ${ }^{12}$ Its Statute has evolved in light of experience, and in accordance with international standards of transparency and due process, as well as parallel litigation before the domestic courts of England and Wales in the early years of operation. To date, the domestic courts have deferred to CSAT jurisdiction, upholding the immunity of the Commonwealth Secretariat from the jurisdiction of the domestic courts of the UK and steering clear of disturbing CSAT arbitral awards on grounds of irregularity. Since 2005, the Tribunal and its members have enjoyed immunity from domestic jurisdiction and its decisions are no longer subject to a statutory appeal function under UK arbitration law. The immunity of CSAT judges has never been tested. ${ }^{13}$

All IATs may be said to be shaped by three factors: (i) what they are able to do- the powers and expectations vested in them by the member States that create them; (ii) what they do in practice-determining questions of contractual relationships frequently relating to employment with the relevant international organization; and (iii) the context in which they operate-applicants from time to time resort to the domestic or regional jurisdiction of the host

8 See ibid, art XıII.2. The current Statute, Rules, judgments and list of members are available online at $<$ https://thecommonwealth.org/tribunal $>$ accessed 3 April 2020.

9 In employment cases, compensation is normally limited to three times net annual remuneration. See ibid, art X.1.

10 Ibid, art XI.

11 Ibid, art XII.

12 As of March 2020.

13 Commonwealth Secretariat Act 1966, s 1(2) and sch, paras 1 and 6. 
country, to address a perceived vacuum in the contractual dispute settlement process available at the international level.

A review of the formation of CSAT, and how and why its Statute has evolved since it was established, provides a useful insight for new international organizations. It may inform the consideration of whether to establish a separate IAT for the organization, or whether to recognize the jurisdiction of an existing IAT that allows for this. This assumes there is an obligation to provide for a dispute settlement forum, as appears to be the case in light of case law and the consistent practice of international organizations. ${ }^{14}$

\section{A Brief History of the Commonwealth Secretariat}

The origins of the Commonwealth may be traced back to the nineteenth century. The association as known today was fused during decolonisation of former dominions from the UK. ${ }^{15}$ In 1949 , the London Declaration recognized India's independence as a Republic while continuing its full membership in the Commonwealth of Nations. ${ }^{16}$ The eight founding members-Australia, Britain, Canada, India, New Zealand, Pakistan, South Africa and Ceylondropped the 'British' prefix and the requirement for allegiance to the British Crown to become 'The Commonwealth of Nations'. Now it is known simply as 'The Commonwealth'. It is not a treaty-based organization but a voluntary association of independent sovereign states. Members can leave without serving notice; and re-join, subject to verification that they comply with the fundamental values set out in the Commonwealth Charter. ${ }^{17}$

At first, the organization was administered by the UK Government's Commonwealth Relations Office. As the membership grew, Commonwealth Prime Ministers decided in 1964 to establish an independent Commonwealth Secretariat. The resultant intergovernmental instrument was concluded by Heads of Government, meeting in London in $1965 .{ }^{18}$ Last updated in 2005, the Revised Agreed Memorandum on the Commonwealth Secretariat (Revised Agreed

14 See for example ICJ, Effect of Awards 1954, 57; Klabbers 2015, 246-252.

15 See the concise history in Roberts 2017; for a more detailed, historical review, see Dale 1982.

16 London Declaration, 26 April 1949.

17 Zimbabwe left in 2003. Pakistan, The Gambia and Maldives have left and re-joined. See Commonwealth Secretariat, 'Our History'. The Charter was adopted at the Commonwealth Heads of Government Meeting (CHOGM) on 14 December 2012 and signed by нM The Queen on Commonwealth Day 2013. See Charter of the Commonwealth (Commonwealth Charter).

See Commonwealth Secretariat, 'Our History'. 
Memorandum $)^{19}$ records that the UK will arrange for the Secretariat to be accommodated in Marlborough House in London. ${ }^{20}$ The memorandum sets out the roles and functions of the Secretariat and of the Secretary-General as its Chief Executive. It assigns to the Secretariat, its staff, and members of CSAT privileges and immunities comparable to those enjoyed by High Commissions. The UK and other Commonwealth members have legislated accordingly, giving the Secretariat legal capacity and privileges and immunities under domestic jurisdictions.

Today, the Commonwealth is a voluntary association of 54 independent, sovereign states, with shared principles and values reflected in the Commonwealth Charter, and, in most cases, a shared common law legal system. ${ }^{21}$ The language of the Commonwealth meetings is English, and many, but not all, member countries have an historic association with the UK. ${ }^{22}$ The combined population of the Commonwealth is 2.4 billion, with more than $60 \%$ under 30 years old. The Commonwealth is one of the largest international organizations after the United Nations, with enormous convening power across the five regions of Africa, Asia, Caribbean and Americas, Pacific, and Europe. It also has two 'sister' organizations, the Commonwealth of Learning and the Commonwealth Foundation, and over 80 Commonwealth Accredited Organizations. ${ }^{23}$

\section{$3 \quad$ Organization and Governance}

The Queen is Head of the Commonwealth. ${ }^{24}$ The principal organs of the Commonwealth are the Commonwealth Heads of Government Meeting (CHOGM) and the Commonwealth Secretariat.

19 Revised Agreed Memorandum, 12 May 2005.

20 Marlborough House is a Royal Palace placed at the disposal of the Commonwealth by HM The Queen since 1964.

21 The Queen is Head of State in 16 of the 54 'member countries', as they are known. Member countries are listed at $<$ https://thecommonwealth.org/member-countries $>$ accessed 3 April 2020.

22 The Edinburgh Communiqué, 27 October 1997, para 20 ("Heads of Government [...] agreed that in order to become a member of the Commonwealth, an applicant country should, as a rule, have had a constitutional association with an existing Commonwealth member; that it should comply with Commonwealth values, principles and priorities as set out in the Harare Declaration; and that it should accept Commonwealth norms and conventions").

23 More information is available at $<$ https://thecommonwealth.org/> accessed 3 April 2020.

24 At the CHOGм 2018 in London, Heads decided that the Prince of Wales should succeed нм The Queen upon her death or abdication. See Cноgм 2018 Leaders' Statement, para 3 . 
CHOGMs are held biennially in a Commonwealth city. Decisions are recorded in a communique at the end of the meeting, and the leader of the country hosting CHOGM is Chair-in-office until the next meeting. The SecretaryGeneral is appointed by the Commonwealth Heads of Government acting collectively. They are to be a person of high standing, and a significant part of their duties entails visiting member countries of the Commonwealth. ${ }^{25}$

The Secretary-General is the Chief Executive of the Commonwealth Secretariat, which has approximately 220 members of staff, across 32 Commonwealth nationalities. The Secretary-General and Secretariat staff derive their functions from the authority of the Heads of Government. They act in the service of the Commonwealth countries collectively. ${ }^{26}$

The Board of Governors (BoG) meets annually or more frequently as required. It approves and monitors the four-year strategic plan and the annual delivery plan and budget. ${ }^{27}$ The BoG is made up of representatives of all Commonwealth governments and is comprised of senior officials of member countries - in practice, at High Commissioner level. An Executive Committee (ExCo) of the BoG meets quarterly, ${ }^{28}$ and an independent Audit Committee, appointed by the ExCo and reporting to the BoG, meets quarterly with the Secretariat and the internal and external auditors.

\section{Resolution of Staff Disputes in the Early Years, and the Decision to} Establish CSAT

From the outset, Heads of Government committed to legislate to provide the Secretariat legal personality and accord certain privileges and immunities. The exceptions were: when privileges and immunities were expressly waived; in respect of motor vehicle accidents; and when arbitration proceedings were

25 Revised Agreed Memorandum, 12 May 2005, para 28. See also Doxey 1989, ch 3. Commonwealth Secretaries-General to date, with country of nomination, are: Arnold Smith (Canada, 1965-1975), Sir Shridath Ramphal (Guyana, 1975-1990), Chief Emeka Anyaoku (Nigeria, 1990-1999), Don McKinnon (New Zealand, 2000-2008), Kamalesh Sharma (India 2008-2016) and the Rt Hon. Patricia Scotland QC (Guyana, 2016 to date).

26 Ibid, para 5 .

27 The strategic plans, reports and financial statements are available at $<\mathrm{https} / /$ thecommonwealth.org/about-us/accounts-internal-reports > accessed 3 April 2020.

28 The role and functions of the BoG and ExCo are set out in the Revised Agreed Memorandum, 12 May 2005, Annex B. 
taken in respect of written contracts. ${ }^{29}$ The Commonwealth Secretariat Act 1966 (1966 Act) provided for disputes to be resolved by arbitration, which could be enforced under the UK's Arbitration Acts. ${ }^{30}$ There was no provision for arbitration under the laws of other Commonwealth countries nor did contracts specify the governing law. In practice, employment and any other disputes were resolved informally. The arbitration process was never formally invoked, although it was already clear that the exception to immunity did not extend to litigation before employment tribunals. ${ }^{31}$

A restructuring of the Secretariat in 1993 brought matters to a head. One staff member, unhappy about redundancy, threatened to take their case to a UK employment tribunal. The then Secretary-General, Chief Anyaoku, after taking advice and consulting the Commonwealth Secretariat Staff Association and member Governments, proposed that Heads of Government amend the Staff Regulations regarding termination of appointment and oblige parties to submit disputes, including employment disputes, to a new CSAT to the exclusion of other fora. According to the Statute of the new tribunal, international administrative law would apply to employment cases. Decisions would be final and binding but could be revised if new facts emerged. ${ }^{32}$

CSAT was modelled on the United Nations and the World Bank Administrative Tribunals. Nonetheless, its jurisdiction extended beyond employment contracts governed by international administrative law, in that it also covered international enforcement of commercial contracts, applying the domestic law governing the contract. Building on the framework set in the Agreed Memorandum, CSAT offered a comprehensive solution to potential contractual disputes involving the Secretariat. In this way, it was ahead of the curve compared to tribunals whose jurisdiction is limited to international administrative law. The case noted above was settled in the end, without resort either to domestic arbitration or to CSAT, but from 1998 there were a series of cases testing the relationship between CSAT and the UK domestic courts.

29 Agreed Memorandum on the Commonwealth Secretariat, paras 39-40 and Annex A.

30 Commonwealth Secretariat Act 1966, s 1(3). The 1966 Act referred to the Arbitration Act 1950 and Arbitration Act (Northern Ireland) 1937, was amended by the Arbitration Act 1996, then omitted by the International Organisations Act 2005.

31 See Court of Appeal of England and Wales, Gadhokv Commonwealth Secretariat 1977, an unfair dismissal case where the employee's application was rejected by the Employment Tribunal, EAT and Court of Appeal. 


\section{How the Early Cases Shaped the Structure of CSAT and the Respective Roles of the Board of Governors and the Commonwealth Secretariat}

This section will now track the history of this reformed csAT under the following seven headings: (i) The 1995 Statute; (ii) The 1998 Rules and the First Hearing; (iii) Amendment to the Statute in 1999-Planning for Contingencies; (iv) Amendment of the Statute in 2004-Fairness, Transparency and Human Rights; (v) Amendment to the Statute in 2005-Immunity from UK Domestic Jurisdiction; (vi) The Sumukan Litigation Clarifies the Position on Immunity; and, lastly, (vii) Further Changes to the Statute in 2007 and 2015-Diversity, Review, Conflicts and Documents Production.

\subsection{The 1995 Statute}

From the outset, as noted above, the Tribunal was given jurisdiction over all contractual disputes involving the Secretariat. Cases could be brought by contractors, the Secretariat or its staff. The Tribunal was initially designed as an arbitral mechanism, entitling parties with contracts with the Secretariat to have disputes settled by arbitration without recourse to dispute settlement under the domestic law of the UK. The effect was to apply the growing body of international administrative law to the activities of the Secretariat rather than the domestic law of any one member State. The Tribunal could only exercise jurisdiction once internal remedies had been exhausted and only if an application had been brought within three months of the dispute arising. An exception could be made where it was not reasonably practicable for the application to be brought within this timeframe. ${ }^{33}$

At its inception on 1 July 1995, the Tribunal was composed of three members. ${ }^{34}$ All were Commonwealth judges, no two being nationals of the same country; of high moral character; and qualified for high judicial office or jurisconsults of recognized competence with at least 10 years' experience. The President, appointed by the Secretary-General, had a three-year term renewable once, while the two remaining members were appointed ad hoc, one by the aggrieved staff member and one jointly by the Secretary-General and the Commonwealth Secretariat Staff Association (CSSA). The Secretariat was responsible for the administrative arrangements and for meeting the Tribunal expenses.

33 Ibid, annexed Draft Statute of the Arbitral Tribunal of the Commonwealth Secretariat, art II.

34 Commonwealth CL No 19/95, 5 June 1995. 
The Statute could be amended by the Secretary-General having consulted the Commonwealth Secretariat Staff Association and Governments.

Subsequently, with the adoption of the Arbitration Act 1996, the UK arbitration landscape changed, and the parties could no longer agree to exclude the right of appeal to the High Court of England and Wales completely. ${ }^{35}$ CSAT decisions could be subject to the jurisdiction of the UK Courts, which could order payment or mandate that the Secretariat take certain actions, thereby subjecting the Secretariat's disputes indirectly to the jurisdiction of the UK domestic courts. The real possibility of challenge was illustrated by the early cases and parallel proceedings before the domestic courts.

\subsection{The 1998 Rules and the First Hearing}

In 1998, with Justice Ulrich Cross of Trinidad presiding, CSAT promulgated the 'Rules of the Commonwealth Secretariat Arbitral Tribunal' and delivered its first judgment. ${ }^{36}$ In Hans (1998) an international recruit, appointed by the Secretariat and based at the Commonwealth Youth Programme (CYP), Asia Regional Centre in Chandigarh, India, was unable to bring their dispute before the local employment tribunal in view of the Secretariat's immunity from suit. Bound by the principles of international administrative law under Article XII of its Statute, CSAT determined the purpose of probation with reference to jurisprudence of the World Bank and International Labour Organisation Administrative Tribunals and referred to C.F. Amerasinghe's publication, 'The Law of the International Civil Service.' ${ }^{37}$

The applicant won three months' salary in damages for procedural injustice relating to the early termination of their contract, together with costs of the CSAT hearing; but they were unable to reclaim legal costs relating to the failed proceedings in India. CSAT held that,

[t]he Applicant is at liberty to pursue [their] interest in a court or tribunal which [they think] could redress [their] perceived wrongs. It is not the fault or liability of the Respondents if [the Applicant] chooses a court or tribunal which has no jurisdiction over the Respondents. ${ }^{38}$

35 Arbitration Act 1996.

36 The current Statute, Rules, judgments and list of members are available online at $<\mathrm{htt}-$ ps://thecommonwealth.org/tribunal> accessed 3 April 2020.

37 CSAT, Gurmeet Hans $v$ The Commonwealth Secretariat and Ms Seelawathi Ebert, Regional Director CYP 1998.

38 Ibid, 10. In CSAT, Dr A S Saroha $v$ The Regional Director, CYP (Asia) 2000, a local staff member recruited directly by the CYP: Asia Centre could not bring a case against the Secretariat 


\subsection{Amendment to the Statute in 1999-Planning for Contingencies}

In light of lessons learned from Hans, and having consulted the Tribunal President and the CSSA, Secretary-General Anyaoku amended the Tribunal Statute on 24 June $1999 .{ }^{39}$ The amendments provided for the contingency of the Tribunal President being prevented from sitting, and increased the membership of the panel to the President plus four judges. The Tribunal would normally be composed of the President alone, and could sit as a panel of three in complex matters. Where a substantial number of applications had to be dealt with, separate chambers could be constituted. In addition, the revised Statute provided for an alternate Secretary and for decisions to be taken on the basis of the documents unless oral proceedings were warranted. It also introduced a time limit of 60 days for an application to review the judgment.

Mohsin (2001) tested the system. ${ }^{40} \mathrm{~A}$ former staff member won their case for procedural injustice after a performance review board did not provide them with an opportunity to comment on oral evidence heard in their absence. The oral hearing had been stalled due to the ill health of both the Tribunal President Ulrich, combined with the limited availability of the second Tribunal member, C.F. Amerasinghe, who eventually withdrew. The President designated the third panel member, Anesta Weeks QC, to conclude the case sitting alone, and this was enshrined in an order with the consent of the parties.

The applicant also brought a claim before the UK Courts, under the 1996 Arbitration Act, alleging that the process did not comply with the European Convention on Human Rights, in that there had been extensive delays in determining the case, and the Tribunal was not composed in a way that was sufficiently independent of the Commonwealth Secretariat. The Secretariat pleaded immunity and did not appear in the proceedings. Judge Steel held that the Secretariat had no immunity in respect of arbitration proceedings, applying the decision of the Court of Appeal in Gadhokv Commonwealth Secretariat. ${ }^{41}$ Written evidence disclosed in these domestic proceedings aired the extent to which

for want of jurisdiction, because CYP was a separate legal entity from the Secretariat; CYP also had immunity from Indian jurisdiction.

39 Following Commonwealth CL No 14/99, 29 April 1999; CL No 23/99, 29 June 1999.

40 CSAT, Selina Mohsin $v$ The Commonwealth Secretariat 2001 (CSAT/3 No 1; CSAT/3 No 2). In CSAT 3 No 1, CSAT laid the ground rules for CSAT jurisdiction, being the 'internal law of the organisation' and international administrative law principles to the exclusion of the national laws of member countries, while '[r]eference will be made to judgments of other international administrative Tribunals' as recognized in wBAt, Louis De Merode et al. $v$ The World Bank 1981, para 28.

41 See High Court of England and Wales, Selina Mohsin v The Commonwealth Secretariat 2002, paras 11-12. 
the CSAT judges disagreed over the appropriate way to proceed. Nevertheless, Judge Steel ruled that the claimant had accepted cSAT jurisdiction in their employment contract with the Secretariat; had not challenged before CSAT the decision to proceed with a single arbitrator; and there had been no substantial injustice. The claimant could not show that they "did not know, and could not with reasonable diligence have discovered, the grounds for [their] objection".42

The interface was tested again in Faruqi (2001-2002). The application in CSAT of international administrative law, which governs employment relations of the employees of international organizations, was compared with parallel arguments before the UK domestic courts about privileges and immunities, arbitration and human rights. Unfortunately, due to the illness and eventual retirement of the CSAT President, Ulrich Cross, and a change to the applicant's legal team, an application to CSAT for urgent interlocutory relief could not be addressed for some seven months. The applicant requested interim relief to maintain the status quo in respect of their employment at the Secretariat, together with an order against the Secretary-General for costs to date and assistance with future legal costs and a requirement to consult the applicant over the composition of the Tribunal.

The new csat President, Duncan Chappell, sitting alone, rejected this request. The Tribunal recalled that CSAT was an international body and Article IX of the Statute served as an exclusion agreement from the laws of any country. The European Court of Human Rights (ECHR) had already decided in Waite and Kennedy $v$ Germany that the immunity of international organizations from domestic jurisdiction did not impair the right of access to the courts nor was it disproportionate to the objective of ensuring the proper function of international organizations. ${ }^{43}$ The principles relied on were the same: in international administrative law, as in domestic and regional human rights law, there was an obligation to act impartially and afford a fair hearing. Other regional and international human rights tribunals addressed this. ${ }^{44}$ CSAT concluded:

It would be inappropriate for the Tribunal to adopt in toto any one of these international treaties. Rather, the Tribunal must distil from them the principles that do reflect the essence of international administrative

42 Ibid, para 28.

43 CSAT, Runman Faruqi $v$ The Commonwealth Secretariat 2002 (CSAT/5 No 1), paras 32-38, citing ECtHR, Waite and Kennedy v Germany 1994; ECtHR, Beer and Regan v Germany 1995; Court of Appeal of England and Wales, Gadhokv Commonwealth Secretariat 1977. See also ECtHR, Perez v Germany 2015; ECtHR, Klausecker v Germany 2015. 
law in regard to the provision of an independent and impartial forum for the resolution of disputes. ${ }^{45}$

CSAT decided that general principles of fairness were reflected in the CSAT Statute and the Secretariat's rules and regulations. Moreover, adequate consultation, including with the staff association, ensured a transparent and fair selection process by consensus in accordance with the Commonwealth's governing principles. Urgent interim relief for pecuniary damage was not warranted because compensation, if awarded, could redress such damage.

In parallel domestic proceedings, the UK High Court declined to issue an injunction to stop CSAT from proceeding to a full hearing. Judge Brindle QC considered that any statutory power they had to issue an injunction was limited. It was exercisable only in a "very compelling case where justice could not be done without the grant of an order and the philosophy underlying the Act was not infringed by making such an order". ${ }^{46}$ This was not such a case. CSAT was not a 'public authority' bound by the Human Rights Act 1998, and Article IX of the CSAT Statute was an exclusion agreement preventing an appeal to the domestic courts on a point of law. Nonetheless, the Tribunal President had applied similar principles in international administrative law. Should the applicant pursue High Court litigation after the full CSAT hearing, the prospect of wasted costs, was "not the sort of overwhelming point or the sort of unusual or exceptional circumstance which justifies this court in intervening in the arbitral process". ${ }^{47}$ The High Court declined to issue an interim injunction, which would set a precedent and would be tantamount to opening the floodgates on "nearly every case where a complaint could be made against a provisional ruling". 48

CSAT convened an oral hearing before the full panel of the President, Anesta Weeks and Justice Hassan Jallow. It found that all the parties to the Agreed Memorandum, including the UK, had created an international tribunal whose judgments were final and not subject to further domestic law review. This did not result in a jurisdictional gap compared to the domestic law of member countries. Rather, it meant that CSAT had to apply the 'internal law' of the Secretariat, including the Staff Regulations and Rules, Grievance Procedure and staff rotation policy; and its role was not to act as a merit review body but to

45 Ibid, para $5^{0 .}$

46 High Court of England and Wales, Runman Faruqiv Commonwealth Secretariat 2002, 7.

47 Ibid, 10.

48 Ibid. 
ensure that discretionary authority was properly exercised. ${ }^{49} \mathrm{CSAT}$ upheld the Secretary-General's application of the new staff rotation policy, which had been set by Heads of Government, limiting the length of tenure of senior staff. $^{50}$

An example of collective litigation by staff members of the CssA took place in 2003, when they argued that the Secretariat's decision not to pay Cost of Living Allowance (COLA) was a breach of their contracts of employment. CSAT held that the Secretariat's decision should be rescinded and reconsidered using appropriate methodology. Decisions of the International Labour Organization Administrative Tribunal and other international administrative tribunals demonstrated that there was neither a right to receive the annual cost of living payments nor a right to the automatic indexing of salaries. Furthermore, the CSAT found that there had been adequate consultation with staff about the budget shortfall behind the decision to withhold the COLA, but the information methodology used to prepare the annual budget was inadequate. The Tribunal ordered the Secretariat to pay each cssa member a nominal payment of G BP 100 as compensation..$^{51}$ The applicants did not bring parallel litigation before the UK domestic courts.

\subsection{Amendment of the Statute in 2004-Fairness, Transparency and Human Rights}

By mid-2003, in light of the Faruqi litigation, the CSAT President and members again raised concerns about vulnerability to supervisory jurisdiction of the UK Courts under the 1996 Arbitration Act. A concern was emerging in exchanges with the Tribunal, and within the Secretariat, that Tribunal members-very distinguished judges and jurisconsults in their own right-might have their findings challenged in the UK Courts or even be sued over the way they conducted arbitrations. They might decline to be appointed to CSAT as a result.

The Secretariat faced the following three choices as a result of this dilemma: firstly, accept that the (then) 54 members of the Commonwealth were, as might be perceived, beholden to the jurisdiction of one country-namely the UK; second, abolish the Tribunal, relying on UK employment law alone (which

49 CSAT, Runman Faruqiv The Commonwealth Secretariat 2002 (CSAT/5 No 2), 8.

50 Ibid, 14.

51 CSAT, Commonwealth Secretariat Staff Association v The Commonwealth Secretariat 2003, 12. The ensuing decision to pay an inflation-based cola by lump sum, rather than a regular increase and bonus, was challenged unsuccessfully in CSAT, Simmons and Others $v$ The Commonwealth Secretariat 2005. 
could be expensive in terms of litigation costs and may not be the preference of non-UK staff); or third, accept the jurisdiction of another body, such as the International Labour Organisation Administrative Tribunal if it was willing, thereby 'off-shoring' the resolution of staff matters, out of reach of the jurisdiction of the UK Courts.

Instead, the Secretariat sought to work with the UK as host country, provided that CSAT and its members were immune from the domestic jurisdiction of any member State. This would depend on the UK Government amending the 1966 Act when parliamentary time could be found. Limited time in the legislative programme meant that the issue could not be resolved until 2005 (see Section 5.5, below).

In 2004, Secretary-General McKinnon proposed to Member Governments that the CSAT Statute be reviewed in light of lessons learned and in order to align it with other international administrative tribunals. The aim was to reflect fairness, transparency, and international human rights law principles, consistent with the Secretariat's status as an international organization. There was also a need to limit the potentially large contingent liability to member Governments that would arise if the Tribunal's decisions were open to challenge before the domestic courts of member States. The revisions to Article IV provided for the Tribunal to be composed of three members sitting together, empanelled by and including the President, out of a total component of the President and four other judges, each serving a four-year term renewable once. The President and members would henceforth be selected by Commonwealth Governments for appointment by the Secretary-General, on a regionally representative basis and taking into account views of the Secretary-General and CSSA. CSAT could take account of human rights principles and the practice and procedure of other international tribunals and oral hearings, if convened, would be held in public.

Importantly, henceforth the Statute would be amended by Commonwealth Governments, in consultation with the CsAT President, the Secretary-General and the CSSA. ${ }^{52}$ Thus, from 2004 the Secretary-General pulled back from the facilitating role of appointing judges. From then on, this was done upon selection of the Heads of Government, initially at an Extraordinary Meeting of the BoG on 6 October 2004, and thereafter at BoG meetings or occasionally by correspondence.

$5^{2}$ Revision of 18 February 2004 further to Commonwealth CL No 17/2003, 29 October 2003; CL No 2/2004, 18 February 2004. 


\subsection{Amendment to the Statute in 2005-Immunity from UK Domestic Jurisdiction}

In 2005, the UK amended the 1966 Act to extend immunity from jurisdiction of the UK Courts over written contracts entered into by the Secretariat; to afford immunities to CSAT judges and officials and expert witnesses; and to institute an internal tax system. The International Organisations Act 2005 was brought into force once the BoG approved revisions to the Statute, included as Annex C to the Revised Agreed Memorandum. Proceedings before the Tribunal no longer constituted an 'arbitration' for the purposes of UK domestic law, and the Tribunal judgements were deliverable in an open sitting. ${ }^{53}$

\subsection{The Sumukan Litigation Clarifies the Position on Immunity}

The final case to consider in this series is Sumukan. ${ }^{54}$ This was the only CSAT case based on a commercial contract rather than a staff contract. The applicant company was unsuccessful in a claim for ownership of a website created under a consultancy contract and alleged unfair early termination of the contract. The Secretariat asked the CSAT President to stay on after the expiry of their term to complete these hearings, and the BoG was informed. The consultant then brought a series of proceedings in the UK Courts challenging the outcome.

A director of the company also brought separate proceedings before the employment law courts in London. Their case was dismissed in view of the Secretariat's immunity from suit and legal process under the 1966 Act. ${ }^{55}$ The director argued in the Employment Appeal Tribunal that they had been subject to gender and race discrimination, and that any immunity should therefore be waived because they would otherwise be denied access to a fair hearing in accordance with the European Convention on Human Rights. But Judge Langstaff doubted that the Commonwealth Secretariat was a 'public authority' within the meaning of Section 6 of the UK Human Rights Act 1998, such that immunity had to be waived. The Judge ruled that, "Save in an attenuated sense, an international organization cannot be said to be an arm of any one member

53 Commonwealth BoG, Proposed Amendments to the Statute of the Arbitral Tribunal, 12 May 2005. See also Commonwealth Secretariat Act 1966, s 1(2) and sch, paras 1 and 6.

54 CSAT, Sumukan Ltd $v$ The Commonwealth Secretariat 2003 (CSAT/8 No 1); 2005 (CSAT/8 No 2); 2005 (CSAT/8 No 3 ).

55 Decision of Mr Pearl, chairman sitting alone on 19 September 2005, case number 2201284/2005, upheld on review by Ms Cook (sitting alone), judgment of 16 December 2005. See United Kingdom Employment Appeal Tribunal, Jananyagam v Commonwealth Secretariat 2007, judgment of 12 March 2007, para 9. 
or contracting State, though it may be regarded as an arm of several States acting jointly". ${ }^{56}$ There was an alternative remedy available to the claimant, through the rights of their company to apply to CSAT for breach of contract.

The company also sought to challenge the CSAT decision before the UK Courts, by invoking Section 69 of the Arbitration Act 1996. The UK Courts held that the contract contained an enforceable exclusion agreement with regard to the supervisory jurisdiction of the courts. ${ }^{57}$ The Court of Appeal agreed that the limited waiver did not infringe upon Article 6 of the European Convention on Human Rights, because there remained a possibility of resort to the courts if there was an absence of impartiality or some other irregularity. ${ }^{58}$

In further proceedings before the UK Courts, Sumukan $v$ Commonwealth Secretariat, the company argued that the Tribunal appointment process was not sufficiently independent of the Secretariat. ${ }^{59}$ Lord Justice Toulson presiding, indicated that institutional independence was critical to immunity from suit to be compliant with Article 6 of the ECHR (in other words, the right to a fair trial) ${ }^{60}$ However, the same test did not apply to a case of a contractual dispute. ${ }^{61}$ The court would only intervene if there were a "serious irregularity causing substantial injustice". ${ }^{2}$ At first instance, the judge was not persuaded that procedural defects and lack of consultation with the BoG regarding the de facto extension of the President's tenure posed any "serious irregularity causing substantial injustice" for the purpose of Section 69, but the Court of Appeal held that these defects were fatal and that the Secretariat should have taken all appropriate steps to ensure that the Tribunal members had been properly appointed. ${ }^{63}$ The claimant did not take the case back to CSAT on the merits.

These cases conclusively determined that the Secretariat may invoke immunity before the UK Courts in employment and contract cases. CSAT provides a suitable dispute resolution forum and only in exceptional cases will the UK Courts consider the enforceability of an award. However, the point has not been tested beyond the Court of Appeal. It cannot therefore be ruled out that,

$56 \quad$ Ibid, para 26.

57 High Court of England and Wales, Sumukan Ltd v The Commonwealth Secretariat 2006, paras 20-21.

58 Court of Appeal of England and Wales (Civil Division), Sumukan Ltdv The Commonwealth Secretariat 2007, para 61.

59 High Court of England and Wales, Sumukan Ltd v The Commonwealth Secretariat 2007, para 21 .

6o Ibid, para 66

61 Ibid.

62 Ibid.

63 Court of Appeal of England and Wales (Civil Division), Sumukan Ltd v The Commonwealth Secretariat 2007, para 48. 
despite the latest design of the Tribunal, as it has evolved over time, a significant practical problem could lead to litigation before the UK Courts. An example might be if long-standing vacancies on CSAT lead to a significant delay in dealing with applications, such as to cause a fundamental denial of justice.

\subsection{Further Changes to the Statute in 2007 and 2015 -Diversity, Review, Conflicts and Documents Productions}

Following the Sumukan litigation, the Statute was further revised in 2007, when the Tribunal was expanded from five to eight members and a new review function was introduced, for manifest error of law or fact. Provisions were introduced to ensure gender as well as regional balance; to deal with the eventuality of a member passing away or being otherwise unable to continue sitting; to provide for cases to be determined on the papers; and for the President and other members to continue to sit in an ongoing case, after the expiry of their term, until an application was determined. The meaning of 'Staff' was defined to include those at Commonwealth regional offices, the Commonwealth Youth Programme and the Commonwealth Small States facility in New York. CSAT jurisdiction was expanded to such other international or intergovernmental Commonwealth bodies as may wish to use the Tribunal to settle staff disputes, such as the Commonwealth of Learning or the Commonwealth Foundationin such a way as various other international administrative tribunals allow other organizations to submit to their jurisdiction, notably the Administrative Tribunal of the International Labour Organization. ${ }^{64}$

The Statute was amended again in 2015, to allow the Tribunal to receive late applications in view of extended delay by the Secretariat in taking necessary measures and to provide for recusal in the case of actual or perceived conflict of interest. Other changes empowered the Tribunal to require the production of documents or the attendance of officials as witnesses. These changes were tabled as points of clarification, to remain consistent with developments in other Tribunals, such as the International Monetary Fund Administrative Tribunal, and in light of experience in cases since 2007. ${ }^{65}$

64 Commonwealth CL No 5/2007, 30 March 2007. To date, no such organizations have addressed a declaration to the Secretary-General recognizing CSAT jurisdiction.

65 Commonwealth BoG, Revision of the Statute of CSAT, 28 May 2015; proposals agreed by the Board on the Annual Meeting of the Board of Governors 2015. The amendment to Article vi.4 for rules on application for anonymity followed the decision in CSAT, Julius Ndung'u Kaberere $v$ The Commonwealth Secretariat 2014, paras 15-28. 
The Tribunal, which normally meets at the Commonwealth Secretariat's headquarters at Marlborough House in London, offers accessible and quick access to justice to adjudicate those employment disputes which are not successfully resolved through the internal grievance system. This is highly valued by the Secretariat, its staff and the BoG-which maintains a close interest in any disputes reaching the Tribunal.

A review of CSAT decisions shows a familiar range of workplace complaints, from interpersonal staff relationships that have deteriorated, to alleged unfairness of pay increments, to non-renewal of contracts, regrading and redundancy. ${ }^{66}$ Regular themes include the need to deal with staff cases promptly and fairly, ensuring that decisions are well-reasoned and well-evidenced and the need for transparency - staff cannot be deprived of their rights without due process and due notice. Reference is made in a number of cases to decisions of other international administrative tribunals. Even where there is no express reference, in practice, a background check of case law will have been made to ensure that principles are developed in step with key cases of other international administrative tribunals.

Over time, CSAT and its Statute have evolved in light of the changing context. Changes to the Statute have responded to developments in the legal framework of the headquarter's country, progressive best practice across other international administrative tribunals, and in light of CSAT's own practice and jurisprudence. The Tribunal itself has matured as an independent and effective body, whose Statute and membership are decided upon by governments. As the Tribunal continues to progress, four lessons may be learned going forward:

(i) The overwhelming majority of CSAT cases have concerned employment matters. It is essential that the Tribunal has amongst its members a strong foundation in employment law and experience in managing written and oral proceedings, in addition to the statutory requirement of appropriate geographic representation and gender diversity.

(ii) Vacancies should be filled as soon as notified and not carried for longer than absolutely necessary. Even though the chances of an application being brought appear remote, or it is seen as unlikely that a litigant might challenge a decision by way of review, the Tribunal must be staffed and ready to deal with the possibility. Without sufficient judges, the President

66 Beyond the scope of this chapter. See for example Borda 2013. 
is not in a position to form a Review Board. An inability to hear an appeal could trigger an application to the UK Courts for lack of due process. So might a procedural deficiency in an appointment.

(iii) Judicial members are paid an honorarium and per diem. There might be no cases for a long period of time- or several at once. Although the Tribunal's work may be highly rewarding and a valuable personal contribution to the Commonwealth, care should be taken to ensure that nominees for appointment to the Tribunal are aware of the variable time commitment involved in what is largely voluntary work.

(iv) CSAT was created to provide a forum for settlement of disputes about contracts with the Secretariat, including employment disputes, in view of statutory immunity from the jurisdiction and enforcement of the local courts. Other Commonwealth organizations that enjoy immunity from the domestic jurisdiction of the host country might consider whether to avail themselves of CSAT jurisdiction by making an application under the Statute. Any employment disputes that cannot be resolved informally might otherwise be referred to the local domestic courts, leaving the organization with little alternative to waiving immunity. If no waiver is forthcoming, the organization could face a challenge under domestic law, based on denial of justice.

\section{Reference list}

Agreed Memorandum on the Commonwealth Secretariat (Cmnd 2713, 1965).

Amerasinghe C F, The Law of the International Civil Service: As Applied by International Administrative Tribunals, Volume I (2nd edn, OUP 1994).

Amerasinghe C F, The Law of the International Civil Service: As Applied by International Administrative Tribunals, Volume II (2nd edn, OUP 1994).

Arbitration Act (Northern Ireland) 1937.

Arbitration Act 1950.

Arbitration Act 1996.

Aust A, 'Theory and Practice of Informal International Instruments' (1986) 35(4) International \& Comparative Law Quarterly 787.

Beer and Regan $v$ Germany App No 28934/95 (ECtHR, 18 February 1999).

Borda A Z, 'An Overview of the Commonwealth Secretariat Arbitral Tribunal and Its Use of Discretion in Employment-Related Judgments' (2013) 13(2) Oxford University Commonwealth Law Journal 313 . 
Charter of the Commonwealth (adopted 14 December 2012, signed by HM The Queen on Commonwealth Day 2013) <https://thecommonwealth.org/our-charter> accessed 2 April 2020.

Commonwealth Board of Governors, Proposed Amendments to the Statute of the Arbitral Tribunal (adopted 12 May 2005) BG2(04/05)3b Agenda Item 7 b.

Commonwealth Board of Governors, Revision of the Statute of CSAT (adopted 28 May 2015) BG1(14/15)13 Agenda Item $12 b$.

Commonwealth Circular Letter No.23/94 (10 June 1994).

Commonwealth Circular Letter No 19/95 (5 June 1995).

Commonwealth Circular Letter No 14/99 (29 April 1999).

Commonwealth Circular Letter No 23/99 (29 June 1999).

Commonwealth Circular Letter No 17/2003 (29 October 2003).

Commonwealth Circular Letter No 2/2004 (18 February 2004).

Commonwealth Circular Letter No 5/2007 (30 March 2007).

Commonwealth Circular Letter No 8/2007 (30 April 2007).

Commonwealth Heads of Government, Leaders' Statement (Commonwealth Heads of Government Meeting, United Kingdom, 20 April 2018) < https://thecommonwealth. org/media/news/commonwealth-heads-government-meeting-2018-leaders-statement> accessed 2 April 2020.

Commonwealth Heads of Government, The Edinburgh Communiqué (Commonwealth Heads of Government Meeting, Edinburg, United Kingdom, 27 October 1997) < https://thecommonwealth.org/history-of-the-commonwealth/common wealth-heads-government-meeting-edinburgh-united-kingdom-24-27> accessed 2 April 2020.

Commonwealth Heads of Government, The Harare Commonwealth Declaration (Commonwealth Heads of Government Meeting, Harare, Zimbabwe, 20 October 1991) $<$ https://thecommonwealth.org/harare-declaration> accessed 2 April 2020.

Commonwealth Prime Ministers, London Declaration (Commonwealth Prime Ministers Meeting, London, United Kingdom, 26 April 1949) < https://thecommonwealth. org/london-declaration $>$ accessed 2 April 2020.

Commonwealth Secretariat, 'Commonwealth Secretariat Accounts and Internal Reports' (The Commonwealth) < https://thecommonwealth.org/about-us/accountsinternal-reports $>$ accessed 3 April 2020.

Commonwealth Secretariat, 'Commonwealth Secretariat Administrative Tribunal' (The Commonwealth) <https://thecommonwealth.org/tribunal > accessed 3 April 2020.

Commonwealth Secretariat, 'Homepage' (The Commonwealth) <https://thecommonwealth.org/> accessed 3 April 2020.

Commonwealth Secretariat, 'Member Countries' (The Commonwealth) <https:// thecommonwealth.org/member-countries > accessed 3 April 2020. 
Commonwealth Secretariat, 'Our History' (The Commonwealth) <https://thecommonwealth.org/about-us/history> accessed 3 April 2020.

Commonwealth Secretariat Act 1966.

Commonwealth Secretariat Staff Association $v$ The Commonwealth Secretariat, CSAT Judgment No CSAT/7 (2003).

Dale W, 'Is the Commonwealth an International Organisation?' (1982) 31 International \& Comparative Law Quarterly 451.

Doxey M P, The Commonwealth Secretariat and the Contemporary Commonwealth (1st edn, Palgrave Macmillan 1989).

Dr A S Saroha $v$ The Regional Director, Commonwealth Youth Programme (Asia), CSAT Judgment No CSAT/2 (2000).

Effect of Awards of Compensation Made by the United Nations Administrative Tribunal (Advisory Opinion) [1954] ICJ Rep 47.

Gadhokv Commonwealth Secretariat (1977) 12 ITR 440 (CA).

Gurmeet Hans $v$ The Commonwealth Secretariat and Ms Seelawathi Ebert, Regional Director Commonwealth Youth Programme, CSAT Judgment No CSAT/1 (1998).

International Organisations Act 2005.

Jananyagam v Commonwealth Secretariat [2007] U KEAT 0443_06_1203, 12 March 2007.

Julius Ndung'u Kaberere $v$ The Commonwealth Secretariat, CSAT Judgment No CSAT APL/20 (No 1) (2014).

Klabbers J, An Introduction to International Organizations Law (3rd edn, CUP 2015).

Klausecker v Germany App No 415/07 (ECtHR, 6 January 2015).

Louis de Merode et al. $v$ The World Bank, WBAT Decision No 1 (1981).

Perez v Germany App No 15521/o8 (ECtHR, 6 January 2015).

Revised Agreed Memorandum on the Commonwealth Secretariat (12 May 2005) < https://thecommonwealth.org/sites/default/files/inline/Revised\%2oAgreed\%2o Memorandum\%202005.pdf> accessed 2 April 2020.

Roberts I, 'Chapter 23: Other International and Regional Organizations: Commonwealth, NATO, Council of Europe, OAS, AU, ASEAN, CIS, Francophonie, Arab League, Organization of Islamic Cooperation, Gulf Cooperation Council, OsCE' in Roberts I (ed), Satow's Diplomatic Practice (7th edn, oup 2017).

Runman Faruqi $v$ The Commonwealth Secretariat, cSAT Judgment No CSAT/5 (No 1) (2002).

Runman Faruqi $v$ The Commonwealth Secretariat, CSAT Judgment No CSAT/5 (No 2) (2002).

Runman Faruqiv Commonwealth Secretariat [2002] EWHC 681 (Comm).

Selina Mohsin v The Commonwealth Secretariat, CSAT Judgment No CSAT/3 (No 1) (2001).

Selina Mohsin $v$ The Commonwealth Secretariat, CSAT Judgment No CSAT/3 (No 2) (2001). 
Selina Mohsin v The Commonwealth Secretariat [2002] EW HC 377 (Comm).

Simmons and Others $v$ The Commonwealth Secretariat, CSAT Judgment No CSAT/9 (2005).

Statute of the Commonwealth Secretariat Arbitral Tribunal (adopted 1 July 1995, amended 24 June 1999, 18 February 2004, 14 May 2005, 16 May 2007 and 28 May 2015).

Sumukan Ltd $v$ The Commonwealth Secretariat, CSAT Judgment No CSAT/8 (No 1) (2003).

Sumukan Ltd $v$ The Commonwealth Secretariat, CSAT Judgment No CSAT/8 (No 2) (2005).

Sumukan Ltd $v$ The Commonwealth Secretariat, CSAT Judgment No CSAT/8 (No 3) (2005).

Sumukan Ltdv The Commonwealth Secretariat [2006] EWHC 304 (Comm).

Sumukan Ltd $v$ The Commonwealth Secretariat [2007] EWCA Civ 243.

Sumukan Ltdv The Commonwealth Secretariat [2007] EWHC 188 (Comm).

Waite and Kennedy v Germany App No 26o83/94 (ECtHR, 18 February 1999). 